\title{
Intersectionality: A Means for Addressing the Needs of Children with Mental Health Issues who are Engaged with the Family Law and Criminal Justice Systems?
}

\section{Jennifer Bergman*}

Huge numbers of children in Canada suffer from mental health issues, yet only a fraction gets needed supports and services. Left untreated, childhood mental illnesses carry serious consequences for children, families, and society as a whole. This public health crisis is significantly more pronounced for children who are engaged with the family law (child welfare) and youth criminal justice systems ("crossover youth"). Crossover youth face multiplicative challenges, including disproportionate rates of mental health issues. In this article, I explore how the failure to provide crossover youth with needed supports and services, and the related dire consequences suffered by these children and society more generally (e.g. deteriorating mental health, repeated engagement in the criminal justice system) is tied to the failure in the family law (child welfare) and youth criminal justice systems to recognize the effects of the intersection of the various challenges and disadvantages (e.g. poverty, racism, instability) experienced by these children. I describe the paradigm of intersectionality, and argue that the adoption of an intersectional approach by the family law (child welfare) and youth criminal justice systems is imperative in order for the legal system to meet its mandate and protect and promote the well-being of these vulnerable children.

Un nombre effarant d'enfants du Canada souffrent de problèmes de santé mentale; pourtant, peu d'entre eux reçoivent le soutien et les services dont ils ont besoin. Malheureusement, les problèmes de santé mentale non traités dès l'enfance entraînent de très graves conséquences pour les enfants, les familles et l'ensemble de la société. La crise de santé publique que nous vivons actuellement est beaucoup plus prononcée pour les enfants qui sont suivis tant par le système de justice familiale (protection de l'enfance) que par celui de la justice pénale pour les adolescents (" crossover youth" ou " jeunes sous double autorité »). Les jeunes sous double autorité font face à de nombreux défis, dont des taux démesurés de problèmes de santé mentale. Dans cet article, j'explore les liens entre, d'une part, les graves conséquences qui découlent, pour ces enfants et pour l'ensemble de la société, de l'omission d'offrir à ces jeunes les services et le soutien dont ils ont besoin (p. ex. détérioration de la santé mentale, démêlés répétés avec le système de justice pénale) et, d'autre part, l'absence de reconnaissance, au sein des systèmes de justice familiale

\footnotetext{
SJD Candidate, Faculty of Law, University of Toronto. This article has been developed from research for my LL.M. thesis, The Systemic Failure to Protect Children with Mental Health Issues: An Analysis of the Failings of the Family Law and Criminal Justice Systems (University of Toronto, 2018). I would like to thank Professor Trudo Lemmens of the University of Toronto for his guidance and two anonymous referees as well as the WYAJ Editorial Board for their comments on earlier drafts of this article. I would also like to thank the Law Foundation of British Columbia for providing funding for my LL.M. and SJD work.
} 
(protection de l'enfance) et de justice pénale pour les adolescents, de la corrélation entre les différents défis et problèmes auxquels ces enfants doivent faire face (pauvreté, racisme, instabilité). Je décris le paradigme de l'intersectionnalité et je soutiens que l'adoption d'une approche intersectorielle par les systèmes de justice familiale (protection de l'enfance) et de justice pénale pour les adolescents est impérative afin que notre système de droit accomplisse sa mission et protège et favorise le bien-être de ces enfants vulnérables.

\section{INTRODUCTION}

Huge numbers of children in Canada suffer from mental health issues. ${ }^{1}$ Children's mental illness is a significant public health crisis, with as many as one in five children experiencing mental health issues. ${ }^{2}$ Yet, only about twenty percent of these children gets needed supports and services. ${ }^{3}$ The failure to treat childhood mental illnesses (e.g. conduct disorders, depressive disorders) imposes significant difficulties and carries serious short-term (e.g. developmental and educational difficulties), long-term (e.g. persisting mental illness, unemployment, family breakdown), and societal (e.g. lost productivity, economic costs) consequences for children, families, and society as a whole. ${ }^{4}$ The situation is even more dire for children who are engaged with the family law (child welfare) and youth criminal justice systems ("crossover youth").

Crossover youth experience mental health issues at significantly higher rates than children in the general population. ${ }^{5}$ Despite the elevated prevalence of mental health issues amongst these children, only

1 Ashok Malla et al, "Youth Mental Health Should Be a Top Priority for Health Care in Canada" (2018) 63 Can J Psychiatry 216 at 217; Susan B Stern et al, "When They Call, Will They Come? A Contextually Responsive Approach for Engaging Multistressed Families in an Urban Child Mental Health Center: A Randomized Clinical Trial" (2015) 25 Research on Soc Work Practice 549 at 549.

2 Malla et al, supra note 1 at 217; Peter J Gill et al, "Emergency Department as a First Contact for Mental Health Problems in Children and Youth" (2017) 56 J American Academy Child \& Adolescent Psychiatry 475 at 475; Vicki Schwean \& Susan Rodger, "Children First: It's Time to Change! Mental Health Promotion, Prevention, and Treatment Informed by Public Health, and Resiliency Approaches" (2013) 28 Can J School Psychology 136 at 137.

3 Gill et al, supra note 2 at 475; Schwean \& Rodger, supra note 2 at 137; Malla et al, supra note 1 at 217-18.

4 Malla et al, supra note 1 at 217, 218; Stern et al, supra note 1 at 550; Schwean \& Rodger, supra note 2 at 137, 138-39.

5 The Honourable Justice Brian Scully \& Dr Judy Finlay, "Cross-over Youth: Care to Custody" (2015) Report completed on behalf of the Cross-over Youth Committee, Toronto, Ontario, online: <https://docplayer.net/64549375-Cross-overyouth-care-to-custody.html> at 3; Nicholas Bala et al, "Child Welfare Adolescents \& the Youth Justice System: Failing to Respond Effectively to Crossover Youth" (2015) 19 Can Crim L Rev 129 at 139; Melissa Van Wert et al, "Which Maltreated Children are at Greatest Risk of Aggressive and Criminal Behavior? An Examination of Maltreatment Dimensions and Cumulative Risk" (2017) Child Abuse \& Neglect 49 at 59; Emmeline Chuang \& Rebecca Wells, "The Role of Inter-agency Collaboration in Facilitating Receipt of Behavioral Health Services for Youth Involved with Child Welfare and Juvenile Justice" (2010) 32 Children \& Youth Services Rev 1814 at 1814; Lauren F Freedman, Jennifer S Wong \& Raymond R Corrado, "Risk Profiles and Serious Antisocial Behaviors of Incarcerated Children in Care" (2017) 40 J Crim \& Justice 138 at 139-40, 149-50; Sarah McCormick, Michele Peterson-Badali \& Tracey A Skilling, "Mental Health and Justice System Involvement: A Conceptual Analysis of the Literature" (2015) 21 Psychol Pub Pol'y \& L 213 at 213; Michele Peterson-Badali et al, "Mental Health in the Context of Canada's Youth Justice System" (2015) 19 Can Crim L Rev 5 at 6-7. 
a small number of them receive adequate services. ${ }^{6}$ Where timely and effective services are not provided, crossover youth with mental health issues may become enmeshed in a "downward spiral", with their mental states deteriorating and their related suffering and experiences of disadvantage worsening. ${ }^{7}$ As a result, a significant number of crossover youth find themselves caught in a "vicious cycle", with existing behavioural or mental health issues being exacerbated, and additional difficulties being created and compounded, including multiple moves between residential placements (generally group homes) and repeated engagement with the criminal justice system. ${ }^{8}$

Determining why crossover youth are not receiving needed supports and services is imperative in order to enable the legal system to better serve these children. Early intervention, and adequate and appropriate treatment, may mitigate the negative impact and consequences childhood mental health issues can have on these children, as well as on families and society more generally. ${ }^{9}$ In this article, I explore how the failure to meet the needs of crossover youth relates to the tendency in the family law (child welfare) and youth criminal justice systems to treat children as generic, thereby overlooking how various factors (e.g. poverty, racism, sexism) intersect to shape the different experiences and circumstances these children face and the negative impact this can have on their well-being. I argue that the adoption of an intersectional approach in the family law (child welfare) and youth criminal justice systems would produce deeper understandings of the unique circumstances facing individual crossover youth and shed light on the type and breadth of supports and services they need to thrive. The recognition of crossover youth's multifaceted needs is an imperative first step towards providing these children with the supports and services needed to properly protect them and promote their well-being, along with the well-being of families and of society as a whole.

I begin by providing a brief overview of who crossover youth are, and the types of struggles and challenges they face. Next, I explain what intersectionality means and illustrate what an intersectional analysis involves, using the consideration of determinants of mental health as an example. I then explore how children are treated as generic within the legal system and why statutory remedies aimed at addressing discriminatory outcomes actually perpetuate oppression. Thereafter, I review the demographics and characteristics of crossover youth, examine why an intersectional analysis is required when dealing with this population, and demonstrate the consequences of the failure to undertake this analysis. Finally, I consider how the adoption of a truly intersectional analysis could promote the well-being of crossover youth with mental health issues and enable the state to better meet its duty to protect these vulnerable children.

6 Bala et al, supra note 5 at 135-37, 139, 142; Chuang \& Wells, supra note 5 at 1814; Scully \& Finlay, supra note 5 at 3, 25.

7 Malla et al, supra note 1 at 217,219; Bala et al, supra note 5 at 142; Scully \& Finlay, supra note 5 at 3, 25; Office of the Provincial Advocate for Children and Youth for Ontario, Statement on Child and Youth Mental Health in Ontario (Toronto: Office of the Provincial Advocate for Children and Youth for Ontario, 2011) at 3.

8 Scully \& Finlay, supra note 5 at 2-3, 6; Bala et al, supra note 5 at 135-37, 139, 142, 149.

9 Malla et al, supra note 1 at 217-20; Scully \& Finlay, supra note 5 at 2, 25; Freedman, Wong \& Corrado, supra note 5 at $141,149,150$. 


\section{WHO ARE CROSSOVER YOUTH?}

Children who are engaged with both the family law (child welfare) and youth criminal justice systems are described in the literature by a variety of terms, including "crossover children", "crossover youth", "crossover kids", "dually-involved youth" and "dually-adjudicated youth". ${ }^{10}$ At the "broadest level", "crossover children" or "crossover youth" generally refers to children who have been maltreated and who have engaged in delinquent behaviour. ${ }^{11}$ The terms "dually-involved youth" and "dually-adjudicated youth" are generally considered to be subsets or subgroups of "crossover children" or "crossover youth". ${ }^{12}$ The term "dually-involved youth" is used to describe children who are involved with or receiving services from both the Children's Aid Society [CAS] and the youth criminal justice system. ${ }^{13}$ And, "duallyadjudicated youth" refers to a further subset group, being children who are involved with both the family law (child welfare) and youth criminal justice systems, and are subject to concurrent legal proceedings in both systems. ${ }^{14}$

Numerous authors have recognized the difficulties in providing "precise definitions" to categorize and describe the unique circumstances of the individual children who become engaged with the family law (child welfare) and youth criminal justice systems. ${ }^{15}$ Authors like Nicholas Bala et al caution that, while the "terms have some descriptive utility", using these labels may "obscure the fact that these are individuals with unique needs", and also may fail to acknowledge that "it is not the youth who "crosses over,' but rather the systems". ${ }^{16}$ These labels also may be somewhat misleading insofar as they suggest that these children are engaged in only two systems - family law (child welfare) and criminal justice where in reality many of these children also may need the services of, or be involved with, other systems, including the education (or special education) system and the mental health system. ${ }^{17}$ While being cognizant of the individual circumstances of the children involved in the family law (child welfare) and youth criminal justice systems, particularly those who are struggling with mental health issues, for ease of reference in this article, I use the term "crossover youth" to refer to persons under eighteen years of age who have child protection needs (e.g. a child who is in need of state protection as a result of physical abuse perpetrated by a parent) and who have engaged in delinquent behaviour (e.g. have come to the attention of the police for stealing).

As I elaborate below, crossover youth face multiplicative challenges and complex problems, including higher rates of mental health issues and of incarceration than their counterparts in the general population. ${ }^{18}$

10 Bala et al, supra note 5 at 133; Denise C Herz, Joseph P Ryan \& Shay Bilchik, "Challenges Facing Crossover Youth: An Examination of Juvenile-Justice Decision Making and Recidivism” (2010) 48 Fam Ct Rev 305 at 305-06.

11 Bala et al, supra note 5 at 133; See also Herz, Ryan \& Bilchik, supra note 10 at 305-06; Denise C Herz et al, Addressing the Needs of Multi-System Youth: Strengthening the Connection Between Child Welfare and Juvenile Justice

(Washington, DC: Center for Juvenile Justice Reform, 2012) at 1.

12 Herz, Ryan \& Bilchik, supra note 10 at 305; Bala et al, supra note 5 at 133.

13 Bala et al, supra note 5 at 133; Herz et al, supra note 11 at 13, 1-2; Herz, Ryan \& Bilchik, supra note 10 at 306.

14 Bala et al, supra note 5 at 133; Herz, Ryan \& Bilchik, supra note 10 at 306; Herz et al, supra note 11 at 2.

15 Bala et al, supra note 5 at 133; Herz et al, supra note 11 at 1.

16 Supra note 5 at 133; See also Scully \& Finlay, supra note 5 at 2.

17 Scully \& Finlay, supra note 5 at 2; Bala et al, supra note 5 at 133.

18 Scully \& Finlay, supra note 5 at 3,6; Bala et al, supra note 5 at 139-40; Van Wert et al, supra note 5 at 59; Chuang \& Wells, supra note 5 at 1814, 1820; Freedman, Wong \& Corrado, supra note 5 at 139-40, 149-50; McCormick, PetersonBadali \& Skilling, supra note 5 at 213; Peterson-Badali et al, supra note 5 at 6-7. 
A significant number have experienced maltreatment (e.g. emotional, sexual and/or physical abuse, neglect), trauma, social marginalization and subordination (e.g. poverty, racism, sexism), caregiver functional issues (e.g. mental health or addiction issues), and instability (e.g. multiple residential placements). ${ }^{19}$ The intersecting challenges crossover youth often face, the difficulties involved in adequately addressing these complex problems, and the consequences for the youth and society more generally, may be illustrated by considering Children's Aid Society of Waterloo (Regional Municipality) $v . R$. (K.) $[R$. (K.)], a case involving an application by a CAS to have a young person committed to a secure (locked) mental health treatment facility. ${ }^{20}$

The case of $R$. (K.) involved a fifteen-year-old girl who had been "exposed to alcohol and drugs in utero" and had been apprehended at five years old as a result of "serious neglect, physical abuse and sexual abuse". ${ }^{21}$ During her ten years in care she had been moved twelve to fourteen times between primary placements in foster homes, group homes, and treatment homes. ${ }^{22}$ She came into care exhibiting "a lot of behavioural issues stemming from the serious neglect and abuse" she suffered. ${ }^{23}$ During her time in care (and the twelve to fourteen residential moves experienced in those ten years), those "behavioural issues" had continued and worsened. ${ }^{24}$ She engaged in serious self-harming behaviours, including lying down in traffic, refusing medication, cutting herself, and eating glass, stones and screws. ${ }^{25}$ She had been hospitalized numerous times and diagnosed with numerous mental disorders and a learning disability. ${ }^{26}$ In the approximately three years since being placed in her group home, she had been involved in numerous altercations with staff and had been engaged with the police on over sixty occasions. ${ }^{27}$ She had incurred a number of criminal charges and convictions and had been detained in custody several times. ${ }^{28}$

Having considered the facts of the case and being satisfied that the legislative criteria for committal were met, the Court ordered that the youth in $R$. (K.) be committed to a secure treatment program for a period of six months. ${ }^{29}$ The treatment services the youth was to receive in the secure treatment facility were expected to meet her needs and to help her with "behaviour management". ${ }^{30}$ The focus of the analysis in $R$. (K.), as in other cases involving applications for committal to secure treatment, was whether the youth could be said to have a "mental disorder", as defined in the legislation, and whether the other

19 Bala et al, supra note 5 at 130, 134-39; Scully \& Finlay, supra note 5 at 2-3, 5, 25-26; Carrie Smith et al, "Role Specialization and Service Integration in Child Welfare: Does Organizational Structure Influence the Decision to Refer to Supportive Services?" (2017) 82 Children \& Youth Services Rev 139 [Smith et al, "Role Specialization and Service Integration"] at 139; Lil Tonmyr et al, "Anxiety and/or Depression in 10-15-Year-Olds Investigated by Child Welfare in Canada" (2011) 48 J Adolescent Health 493 at 493; Van Wert et al, supra note 5 at 50, 58; Herz et al, supra note 11 at 16.

20 Children's Aid Society of Waterloo (Regional Municipality) $v R(K), 2009$ ONCJ 684, 186 ACWS (3d) $418[R(K)]$ at para 1; See also Child, Youth and Family Services Act, 2017, SO 2017, c 14, Schedule 1 [CYFSA], ss 157, 158(1), 159.

21 Supra note 20 at para 4.

$22 \quad$ Ibid at para 5.

23 Ibid.

24 Ibid.

$25 \quad$ Ibid at paras 7, 8.

26 Ibid at paras 8, 18-21.

27 Ibid at paras 7, 23.

28 Ibid at paras 7, 10-12, 39.

29 Ibid at paras, 24, 27-29, 32, 43, 44; See also CYFSA, supra note 20, s 164.

$30 \quad R(K)$, supra note 20 at para 28 . 
legislative criteria for committal were satisfied (e.g. effective prevention of serious bodily harm, availability of appropriate treatment at the facility). While this analysis may have resulted in, and hopefully did result in, treatment services that could help to address some of the youth's mental health issues, the analysis and resulting disposition, a period of committal to secure treatment, does not address the other complex challenges the youth was facing, or the ways these multifaceted challenges intersected with, and compounded, her mental health issues.

Despite the depth and breadth of the challenges they face, and their involvement with legal systems mandated to protect and promote their well-being, a significant proportion of crossover youth are not getting the supports and services they need, and the difficulties they face are being compounded and exacerbated by the additional challenges they experience while engaged with the family law (child welfare) and youth criminal justice systems (e.g. multiple moves, detention). ${ }^{31}$ Many of these children experience extensive and ongoing negative outcomes, including continuing (and worsening) mental health issues and repeated engagement with the criminal justice system. ${ }^{32}$ As I will argue, the occurrence and compounding of these negative outcomes is tied to the failure of the family law (child welfare) and youth criminal justice systems to recognize the effects of the intersection of the various challenges and disadvantages experienced by crossover youth.

\section{INTERSECTIONALITY}

\section{A. Intersectionality: A Theoretical Paradigm}

Intersectionality is a theoretical paradigm that draws attention to the "dynamics of difference and sameness", exploring how various different characteristics interact (intersect) to produce various power dynamics and interlocking oppressions. ${ }^{33}$ The paradigm is premised on the notion that individuals' social positions or locations are shaped and defined by various characteristics: race, ethnicity, class, gender, sexual orientation, age, culture, (dis)ability, religion, etc. ${ }^{34}$ Rejecting the notion that social position is defined by any single characteristic (e.g. wealth), intersectional explanations of inequalities seek to reveal how various characteristics (e.g. race, gender) intersect to marginalize some and empower others. ${ }^{35}$ As

31 Bala et al, supra note 5 at 135-37, 139, 142; Chuang \& Wells, supra note 5 at 1814; Scully \& Finlay, supra note 5 at 3 , 6, 25; Freedman, Wong \& Corrado, supra note 5 at 149-51.

32 Malla et al, supra note 1 at 217, 219; Bala et al, supra note 5 at 139, 142; Scully \& Finlay, supra note 5 at 3, 6, 25; Chuang \& Wells, supra note 5 at 1814.

33 Sumi Cho, Kimberlé Williams Crenshaw \& Leslie McCall, "Towards a Field of Intersectionality Studies: Theory, Applications, and Praxis" (2013) 38 Signs 785 at 787, 795; Shelley L Brown, Natalie J Jones \& Leigh Greiner, "Taking Stock of the Intersection of Race, Gender, and Crime: Statistics, Theory, and Correctional Applications" in Marie L Miville \& Angela D Ferguson, eds, Handbook of Race-Ethnicity and Gender in Psychology (New York: Springer, 2014) 151 at 179 .

34 John Cairney, Scott Veldhuizen \& Terrance J Wade, “Intersecting Social Statuses and Psychiatric Disorder: New Conceptual Directions in the Social Epidemiology of Mental Disorder" in John Cairney \& David L Streiner, eds, Mental Disorder in Canada: An Epidemiological Perspective (Toronto: University of Toronto Press, 2010) 48 at 55-56; Brown, Jones \& Greiner, supra note 33 at 179; Joanne Minaker, “Appreciating Ashley: Learning About and From the Life and Death of Ashley Smith through Feminist Pedagogy” (2017) 32 CJLS 291 at 301.

35 Cairney, Veldhuizen \& Wade, supra note 34 at 56, 57; Catharine A MacKinnon, "Intersectionality as Method: A Note" (2013) 38 Signs 1019 at 1020; Brown, Jones \& Greiner, supra note 33 at 179; See also Minaker, supra note 34 at 301 ; 
Catharine A. MacKinnon explains, "intersectionality both notices and contends with the realities of multiple inequalities as it thinks about 'the interaction of' those inequalities in a way that captures the distinctive dynamics at their multidimensional interface". ${ }^{36}$

Intersectionality exposes how viewing inequality along a single axis of power or axis of discrimination (e.g. race) overlooks the simultaneously transformative interaction between various axes of power or axes of discrimination (e.g. race and gender) and the inequalities and lived experiences this produces. ${ }^{37}$ In this way, the paradigm recognizes that various oppressions or inequalities may overlap and intersect, combining to shape and compound the differential "life chances" of individuals. ${ }^{38}$ In considering interlocking oppressions and inequalities, intersectionality examines not only the "additive effects" (sum) of two or more characteristics (e.g. race, class, gender), but also the simultaneous or "joint" (multiplicative) effects the interaction of different characteristics may have in constructing and constraining individuals' choices and the circumstances in which their lives are embedded. ${ }^{39}$ For example, a Black child suffering from undiagnosed Attention Deficit Hyperactivity Disorder may sometimes experience the challenges associated with having an undiagnosed mental health issue in ways similar to a White child's experience. ${ }^{40}$ Often, however, the challenges they face will be compounded by the oppression they experience as a racialized minority. ${ }^{41}$ Their experiences may be shaped by the combined effects of mental illness plus race, or they may be shaped by the simultaneous effects of being a Black (racialized) child with a mental health issue. ${ }^{42}$ This complex interaction is further complicated where, as is often the case for crossover youth, the child faces additional compounding realities, including not having stable housing, regular meals, positive relationships with adult caregivers, or specialized educational programming.

The complex and multifaceted nature of the challenges crossover youth face, the ways they may compound and exacerbate one another, and the importance of engaging an intersectional analysis to address these challenges, may be illustrated by considering the circumstances of the youth in the abovereferenced case of $R$. (K.). The young person in $R$. (K.), like so many children in care, had experienced

Toni Williams, "Intersectionality Analysis in the Sentencing of Aboriginal Women in Canada: What Difference Does it Make?" in Emily Grabham et al, eds, Intersectionality and Beyond: Law, Power and the Politics of Location (New York: Routledge Cavendish, 2009) 79 at 97.

$36 \quad$ Supra note 35 at 1019; See also Cairney, Veldhuizen \& Wade, supra note 34 at 56.

37 MacKinnon, supra note 35 at 1020; Cho, Williams Crenshaw \& McCall, supra note 33 at 787, 795; Cairney, Veldhuizen \& Wade, supra note 34 at 56; Williams, supra note 35 at $80-81$.

38 Cho, Williams Crenshaw \& McCall, supra note 33 at 788, 800, 803; MacKinnon, supra note 35 at 1020-21; Cairney, Veldhuizen \& Wade, supra note 34 at 57, 64; Brown, Jones \& Greiner, supra note 33 at 157.

39 Brown, Jones \& Greiner, supra note 33 at 156; Cairney, Veldhuizen \& Wade, supra note 34 at 57; MacKinnon, supra note 35 at 1028; Minaker, supra note 34 at 304.

40 This example is adapted from an example developed by Kimberlé Williams Crenshaw as cited in MacKinnon, supra note 35 at 1028 and in Brown, Jones \& Greiner, supra note 33 at 156; Consider also Rashmi Goel, "Delinquent or Distracted? Attention Deficit Disorder and the Construction of the Juvenile Offender" (2009) 27 Law \& Ineq 1 at 28, 46, 49; Clair White, "Incarcerating Youth with Mental Health Problems: A Focus on the Intersection of Race, Ethnicity, and Mental Illness" (2016) 14 Youth Violence \& Juvenile Justice 426 at 438.

41 Consider MacKinnon, supra note 35 at 1028; Brown, Jones \& Greiner, supra note 33 at 156; Goel, supra note 40 at 3 , 29, 46, 49; White, supra note 40 at 438, 439.

42 Consider MacKinnon, supra note 35 at 1028; Brown, Jones \& Greiner, supra note 33 at 156; Goel, supra note 40 at 3 , $51-52$. 
serious maltreatment and trauma, and the child welfare system had intervened to remove her from these abusive circumstances. However, after being apprehended, the youth continued to lack a stable and loving home environment and to experience serious, and in many cases worsening, challenges. While in care the youth in $R$. (K.) experienced multiple residential placements and ongoing instability, worsening mental health and behavioural issues, ongoing involvement in the criminal justice system and, likely, a number of other challenges and oppressions (e.g. educational difficulties and disruption, sexism, racism, poverty). Yet, in the legal analysis undertaken, these intersecting challenges and the ways they compounded and contributed to her mental health issues remained unaddressed, resulting in a legal "solution" which placed the youth in a secure treatment program for six months to treat her "mental disorder". An intersectional analysis would consider the multifaceted challenges experienced by the youth and their mutually constitutive nature (e.g. how ongoing residential instability, poverty, and the lack of consistent caregiver relationships likely contributed to the worsening of her mental health and behavioural issues, which in turn likely contributed to further moves, instability, and involvement with the criminal justice system). This analysis would permit the fashioning of a solution which could address the legally identified 'problem' (e.g. the youth's "mental disorder") while also taking into account the environmental factors that affected, and are likely to continue to influence, her mental health and overall well-being (e.g. the existence or lack of stable housing, positive relationships with adult caregivers, ongoing counselling and support to address the severe neglect, physical and sexual abuse she has suffered, educational and life skills programing that is responsive to her learning difficulties, job skills and vocational training that is appropriate given her abilities and that has the potential to lead to gainful employment and end the cycle of poverty, etc.).

Intersectionality also calls attention to the role of societal structures and systems in the subordination and marginalization of individuals, and the (re)production of power dynamics and the conditions in which interlocking oppressions and inequalities occur. ${ }^{43}$ With respect to the legal system for example, intersectionality considers how statutory provisions purporting to be neutral may, in fact, create and uphold inequalities and shape individuals" "life chances". ${ }^{44}$ Intersectionality also considers how laws and social policies purportedly designed to address inequality, in practice, continue to perpetuate discrimination and marginalization. ${ }^{45}$ For example, as I discuss more fully below, in the context of child welfare and youth criminal justice, "neutral" and remedial legislative provisions are often applied in a way that interprets the challenges experienced by children and families (e.g. poverty, unstable housing, mental health or addiction issues) as risk factors and thus as justification for more intrusive interventions.

43 Cho, Williams Crenshaw \& McCall, supra note 33 at 797; MacKinnon, supra note 35 at 1020; Cairney, Veldhuizen \& Wade, supra note 34 at 64; Consider also Brown, Jones \& Greiner, supra note 33 at 157; See also Minaker, supra note 34 at 301 .

44 Cho, Williams Crenshaw \& McCall, supra note 33 at 798, 800; Naomi Nichols \& Jessica Braimoh, "Community Safety, Housing Precariousness and Processes of Exclusion: An Institutional Ethnography from the Standpoints of Youth in an 'Unsafe' Urban Neighbourhood" (2018) 44 Critical Sociology 157 at 159; I explore this phenomenon in detail below in relation to the statutory provisions in the CYFSA, supra note 20, and in the Youth Criminal Justice Act, SC 2002, c 1 $[Y C J A]$.

45 Williams, supra note 35 at 81-82, 95; I also explore this phenomenon below. 


\section{B. Determinants of Mental Health}

Intersectional analysis seeks to understand how the interaction of various characteristics produces multiplicative effects that shape and re-shape power dynamics and experiences of overlapping oppressions and inequalities. ${ }^{46}$ Thus, in considering the occurrence and nature of mental health issues from an intersectional perspective, rather than focus solely on, for example, individual biological causes, an intersectional analysis enquires into how various characteristics (or related social positions) influence incidents of mental health issues and what these associations say about causation. ${ }^{47}$ Studies that have considered the relationship between mental health and various characteristics and social positions (e.g. gender, marital status, race, ethnicity, socioeconomic status) suggest that mental health issues (i.e. disorders) are more prevalent amongst individuals occupying disadvantaged social positions. ${ }^{48}$ Research focused specifically on children has similarly suggested the existence of links between socioeconomic disadvantages (e.g. poverty, inadequate housing, single-parent family structure) and the extent of children's mental health issues. ${ }^{49}$

The links between social positions and mental health have often been explained by theories of "social selection" or "social causation", or a combination of both. ${ }^{50}$ Social selection posits that mental health issues (disorders) may produce different social positions (e.g. an individuals' mental health issues impair their ability to earn an income, causing them to live in poverty). ${ }^{51}$ Social causation on the other hand, posits that challenges or disadvantages related to social positions may cause mental health issues (e.g. exposure to stress and/or adversity increases the risk of mental health issues developing). ${ }^{52}$ With the emergence of research indicating that many mental health issues (i.e. diagnosed disorders, such as schizophrenia) are significantly affected by genetics and other biological factors, many researchers now focus on understanding the interaction between biology and social environment and the relevance of each in regards to specific disorders (e.g. schizophrenia versus post-traumatic stress disorder). ${ }^{53}$ In many cases, the risk or occurrence of mental health issues is influenced by the existence or absence and interaction of

46 See Brown, Jones \& Greiner, supra note 33 at 179; Cho, Williams Crenshaw \& McCall, supra note 33 at 795 ; MacKinnon, supra note 35 at 1020; Cairney, Veldhuizen \& Wade, supra note 34 at 57.

47 See Cairney, Veldhuizen \& Wade, supra note 34 at 56; Consider also Carol S Aneshensel, Jo C Phelan \& Alex Bierman, "The Sociology of Mental Health: Surveying the Field" in Carol S Aneshensel, Jo C Phelan \& Alex Bierman, eds, Handbook of the Sociology of Mental Health, 2nd ed (New York: Springer, 2013) 1 at 2.

48 Cairney, Veldhuizen \& Wade, supra note 34 at 50; Aneshensel, Phelan \& Bierman, supra note 47 at $10,12$.

49 Michael H Boyle \& Katholiki Georgiades, "Perspectives on Child Psychiatric Disorder in Canada" in John Cairney \& David L Streiner, eds, Mental Disorder in Canada: An Epidemiological Perspective (Toronto: University of Toronto Press, 2010) 205 at 218.

50 Cairney, Veldhuizen \& Wade, supra note 34 at 50, 51; Aneshensel, Phelan \& Bierman, supra note 47 at 13 ; For a discussion of other theories regarding the links between social positions and mental health see generally, Carol S Aneshensel, Joe C Phelan, \& Alex Bierman, eds, Handbook of the Sociology of Mental Health, 2nd ed (Springer: New York, 2013).

51 Cairney, Veldhuizen \& Wade, supra note 34 at 50; Aneshensel, Phelan \& Bierman, supra note 47 at 10.

52 Cairney, Veldhuizen \& Wade, supra note 34 at 50; Aneshensel, Phelan \& Bierman, supra note 47 at 13.

53 Cairney, Veldhuizen \& Wade, supra note 34 at 50, 51. 
various factors (e.g. genetics, socioeconomic status, trauma, stress, age, exposure to toxins) and mental "disorders" may both produce and be the product of different characteristics and social positions. ${ }^{54}$

In addition to having an effect on, or being affected by, the occurrence of mental health issues, different characteristics and related social positions also can affect the experience and impact of mental health issues and the interactions an individual has with professionals and institutions (e.g. psychiatrists, hospitals). ${ }^{55}$ Different characteristics or social positions may affect whether individuals will see themselves and/or will be diagnosed (labelled) as "mentally ill" (i.e. whether their behaviours or mental states will be characterized as symptomatic of a mental "disorder"). ${ }^{56}$ They may affect help-seeking (i.e. whether assistance is sought) and the nature and type of any treatment that is pursued (e.g. psychotherapy, pharmacotherapy). ${ }^{57}$ And, an individual's characteristics and related social positions may affect the availability and accessibility of, or barriers to (e.g. costs, lack of transportation), treatment. ${ }^{58}$

\section{THE FALSE CONSTRUCT OF THE GENERIC CHILD}

\section{A. Statutory Remedies Perpetuating Interlocking Oppression and Inequality}

On paper, many of the statutory provisions relating to children (e.g. "in need of protection" provisions in child welfare legislation) appear to be "neutral", while others purport to address documented oppression and inequality (e.g. sentencing provisions in youth criminal justice legislation aimed at counteracting the overrepresentation of Indigenous youth in custody). ${ }^{59}$ However, in practice these provisions - both those that are "neutral" and those aimed at rectifying oppression and inequality - may maintain or compound the discrimination and disadvantages experienced by marginalized individuals. ${ }^{60}$ This may occur where laws purporting to be "neutral" are applied "equally", without regard for the interlocking inequality and oppression produced through the interaction of various characteristics or for the role of legal (and other social) systems and structures in creating and perpetuating the subordination of certain individuals. ${ }^{61}$ For example, Judith Mosoff et al argue that "the experience of Indigenous mothers reveals a history of

54 Ibid at 51-53; Consider also Van Wert et al, supra note 5 at 50; Children's Aid Society of Sudbury \& Manitoulin (Districts) v D (D) (1997), 75 ACWS (3d) 862, 1997 CarswellOnt 5089 (WLNext Can) (ONCJ (Prov Div)) [D (D)] at para 15.

55 Aneshensel, Phelan \& Bierman, supra note 47 at 10, 2; Cairney, Veldhuizen \& Wade, supra note 34 at $51,57$.

56 Aneshensel, Phelan \& Bierman, supra note 47 at 2; Consider also Bryn King et al, "Factors Associated with Racial Differences in Child Welfare Investigative Decision-Making in Ontario, Canada" (2017) 73 Child Abuse \& Neglect 89 at 91 .

57 Aneshensel, Phelan \& Bierman, supra note 47 at 2; Cairney, Veldhuizen \& Wade, supra note 34 at 57.

58 King et al, supra note 56 at 91; Aneshensel, Phelan \& Bierman, supra note 47 at 13.

59 Consider Cho, Williams Crenshaw \& McCall, supra note 33 at 798, 800; Nichols \& Braimoh, supra note 44 at 159 ; Judith Mosoff et al, "Intersecting Challenges: Mothers and Child Protection Law in BC" (2017) 50 UBC L Rev 435 at 438-39; Raymond R Corrado, Sarah Kuehn \& Irina Margaritescu, "Policy Issues Regarding the Over-representation of Incarcerated Aboriginal Young Offenders in a Canadian Context" (2014) 14 Youth Justice 40 at 42; Williams, supra note 35 at 80; CYFSA, supra note 20, s 74; YCJA, supra note 44, ss 38(2)(d), 50(1), 3(1)(c)(iv); Criminal Code, RSC 1985, c C-46, s 718.2(e).

60 Consider Cho, Williams Crenshaw \& McCall, supra note 33 at 798, 800; Nichols \& Braimoh, supra note 44 at 159 ; See Mosoff et al, supra note 59 at 438-39; Corrado, Kuehn \& Margaritescu, supra note 59 at 42; Williams, supra note 35 at 80.

61 Consider Cho, Williams Crenshaw \& McCall, supra note 33 at 797, 798; Brown, Jones \& Greiner, supra note 33 at 157 , 179; Mosoff et al, supra note 59 at 438-40; Nichols \& Braimoh, supra note 44 at 159. 
colonialist and racist processes of regulation of Indigenous families, yet child protection law tends to erase this history through the supposedly neutral application of the best interests of the child standard, the key legal principle in child protection law". ${ }^{62}$

Laws purportedly aimed at rectifying inequality and oppression may be applied similarly in a manner that overlooks or masks the unequal power dynamics embedded in legal (and other social) systems and structures and that, rather than remedying them, compound the disadvantages experienced by marginalized and subordinated individuals. ${ }^{63}$ For example, in an effort to curb the overrepresentation of Indigenous youth in custody facilities, sentencing provisions discouraging the use of custody and requiring judges to pay "particular attention to the circumstances of aboriginal young persons" were included in the Youth Criminal Justice Act. ${ }^{64}$ However, as Raymond R. Corrado, Sarah Kuehn and Irina Margaritescu observe, the sentencing provisions as well as many other policies aimed at "addressing the overrepresentation of [Indigenous] offenders have been unsuccessful" and, in some instances, these policies "have even pronounced [Indigenous youths'] adverse situation in the criminal justice system". ${ }^{65}$

The failure of statutory provisions to achieve their remedial aims and the production of worse outcomes for the target population may be due at least in part ${ }^{66}$ to the manner in which these statutory provisions are applied, and particularly how information about the circumstances of the individual is interpreted. ${ }^{67}$ In the criminal justice system (and in the family law system) risk assessment may factor prominently in decision making, both at the sentencing stage and at earlier decision making points in the process. ${ }^{68}$ Where criminogenic risks and needs (e.g. individual level risk factors for criminality) are assessed without taking account of the role of social structures and systems in creating and perpetuating the circumstances experienced by marginalized individuals, intersecting oppressions and inequalities may be masked and the disadvantages experienced by the individual may be seen as "risk factors". 69

Where the disadvantages or inequalities experienced by an individual are construed as risk factors, a link may be drawn between the individuals' circumstances and the likelihood of criminal behaviour. ${ }^{70}$ In

62 Supra note 59 at 438-39; Consider also Vandna Sinha et al, "Understanding the Investigation-Stage Overrepresentation of First Nations Children in the Child Welfare System: An Analysis of the First Nations Component of the Canadian Incidence Study of Reported Child Abuse and Neglect 2008” (2013) 37 Child Abuse \& Neglect 821 at 822-23; King et al, supra note 56 at 89 .

63 Consider Williams, supra note 35 at 80, 87; Mosoff et al, supra note 59 at 438; Corrado, Kuehn \& Margaritescu, supra note 59 at 42, 53; Nichols \& Braimoh, supra note 44 at 159; Cho, Williams Crenshaw \& McCall, supra note 33 at 797.

64 Corrado, Kuehn \& Margaritescu, supra note 59 at 42; YCJA, supra note 44, ss 38(2)(d), 50(1); See also Williams, supra note 35 at 80 .

65 Supra note 59 at 42,41 ; See also Williams, supra note 35 at 80.

66 Sentencing decisions may also be influenced by, amongst other things, policy and administrative decisions in the criminal justice and other systems (e.g. lack of available therapeutic programs or other supports and services) (consider Williams, supra note 35 at 88; $R v S(R), 2014$ ONSC 4279, [2014] OJ No 6498 at paras 8-14; $R v D(W A L)(1), 2004$ SKPC 40, 245 Sask R 98 [D (WAL)] at paras 87-89).

67 Williams, supra note 35 at 80, 87; Corrado, Kuehn \& Margaritescu, supra note 59 at 55, 53.

68 Corrado, Kuehn \& Margaritescu, supra note 59 at 53; Minaker, supra note 34 at 300; Williams, supra note 35 at 80; Consider also YCJA, supra note 44, Preamble.

69 Minaker, supra note 34 at 300; Williams, supra note 35 at 80, 87, 94, 95; Corrado, Kuehn \& Margaritescu, supra note 59 at 53; Regarding criminogenic risks and needs, see also McCormick, Peterson-Badali \& Skilling, supra note 5 at 214; Peterson-Badali et al, supra note 5 at 11-12.

70 Minaker, supra note 34 at 300; Williams, supra note 35 at 80, 87; Corrado, Kuehn \& Margaritescu, supra note 59 at 53; Consider also Bala et al, supra note 5 at 140 . 
the context of remedial sentencing provisions this can mean that the circumstances the statute is aimed at addressing (oppression and inequality) and that the Court is mandated to consider, are seen as individual level risk factors which militate in favour of harsher sanctions (e.g. custodial sentences) to contain and reduce the (perceived) risk posed by the individual. ${ }^{71}$ For example, where the sexual abuse, homelessness, or mental health and substance abuse issues experienced by a child are construed only as individual risk factors without consideration of the social context in which they arose, incarcerating the child may appear to be the appropriate solution and the best means for containing the threat of further criminal activity. ${ }^{72}$ The perpetuation of interlocking oppression and inequality may be particularly pronounced for minority groups (e.g. female or Indigenous children) as assessments of risk are speculative and may be "morally laden subjective assessments" and reflective of "white, Western middle class judgement". ${ }^{73}$

The characterization of a child's or family's circumstances (experiences of interlocking oppression and inequality) as risk factors may similarly militate in favour of more intrusive state intervention or scrutiny in the child welfare context. ${ }^{74}$ For example, as Mosoff et al argue, "[p]oor, single mothers especially are constructed as a "risk class' ... who can legitimately be intruded upon, scrutinized indefinitely and held to account for their daily activities"." ${ }^{75}$ This increased scrutiny may be imposed also on families perceived as experiencing other or additional risk factors, such as intimate partner violence, caregiver mental health or addiction issues, child functioning issues, etc. ${ }^{76}$ The Courts have recognized that, as Justice O'Connell stated in Children's Aid Society, Region of Halton v. W. (A.), "[i]t is important not to judge the parent by a middle-class yardstick, one that imposes unrealistic and unfair middle-class standards of child care upon a poor parent of extremely limited potential, provided that the standard used is not contrary to the child's best interests". ${ }^{77}$ However, in some cases Courts nevertheless have found that child protection workers may have imposed "middle class standards" on caregivers in assessing their parenting capacities. ${ }^{78}$

\section{B. Othering}

The ways the children and families that become engaged with the family law (child welfare) and youth criminal justice systems are seen, and how their issues or problems are framed, may be influenced by various (intersecting) characteristics and social positions. ${ }^{79}$ In assessing and making decisions about the children and families with whom they come into contact, child protection workers and judges (amongst others) may be influenced, often unconsciously, by perceptions and biases about marginalized individuals

71 Williams, supra note 35 at 92, 80, 87; See also Corrado, Kuehn \& Margaritescu, supra note 59 at 53; Minaker, supra note 34 at 300 .

72 Consider Corrado, Kuehn \& Margaritescu, supra note 59 at 53; Williams, supra note 35 at 87, $92,95$.

73 Corrado, Kuehn \& Margaritescu, supra note 59 at 53; See also Minaker, supra note 34 at 300.

74 Mosoff et al, supra note 59 at 438.

75 Ibid; Consider also Sinha et al, supra note 62 at 822-23; D (D), supra note 54 at para 29.

76 Mosoff et al, supra note 59 at 440, 444; Consider also D (D), supra note 54 at paras 29-33.

77 Children's Aid Society, Region of Halton $v W(A), 2016$ ONCJ 358, 268 ACWS (3d) 585 [W (A)] at para 292; Consider also $D(D)$, supra note 54 at para 14 .

78 See e.g. $W(A)$, supra note 77 at para 292; Consider also $D(D)$, supra note 54 at para 14; King et al, supra note 56 at 89.

79 See Minaker, supra note 34 at 296; Theresa Glennon, “The Developmental Perspective and Intersectionality" (2016) 88

Temp L Rev 929 at 930-31; Brown, Jones \& Greiner, supra note 33 at 164; Consider also Michael L Perlin \& Alison J Lynch, “'She's Nobody's Child/The Law Can't Touch Her At All': Seeking to Bring Dignity to Legal Proceedings Involving Juveniles" (2018) 56 Fam Ct Rev 79 at 87-88. 
and groups. ${ }^{80}$ These often unconscious perceptions and biases may reflect dominant (majority) societal views and stereotypes about minority groups, conceptions which may be embedded in social structures and systems and may inform dominant notions of what constitutes "normal" or "acceptable" ways of being (e.g. acceptable behaviour, normal mental states). ${ }^{81}$

The way an individual is perceived may affect how behaviours (e.g. delinquent acts) are interpreted and whether they are attributed to individual (internal) factors or environmental (external) factors. ${ }^{82}$ Attributions as to cause(s) of behaviour, may in turn affect the level of responsibility ascribed to the individual for their actions. ${ }^{83}$ For example, where a child has been found guilty of a criminal act and their behaviour is attributed to internal causes, they may be seen to be more responsible for their actions (and more dangerous) and their sentence fashioned accordingly. ${ }^{84}$

The injustice and oppression experienced as a result of the intersection of various characteristics by marginalized children and families, is often imbedded in the very systems that are mandated to protect and assist them. ${ }^{85}$ Practices that, though likely not overtly discriminatory, perpetuate inequality and oppression may permeate the family law (child welfare) and youth criminal justice systems and affect decisions made along the service continuum, including school personnel's decisions to make reports to the CAS, police officers' decisions regarding arrests and diversion, child protection workers' decisions regarding intervention and service provision, and judges' remand and sentencing decisions. ${ }^{86}$ Where decisions are affected by attributions made on the basis of (unconscious) perceptions and biases or stereotypes associated with the characteristics and social positions of the child or their family, interlocking oppression and inequality may be perpetuated, and marginalized individuals further disadvantaged. ${ }^{87}$

80 See Perlin \& Lynch, supra note 79 at 87-88; Ontario Human Rights Commission, Interrupted Childhoods: Overrepresentation of Indigenous and Black Children in Ontario Child Welfare, ISBN 978-1-4868-1117-5 (Toronto: Ontario Human Rights Commission, February 2018) at 26-27; Glennon, supra note 79 at 930-31; Goel, supra note 40 at 38-39; Thomas A Mayes, "Understanding Intersectionality between the Law, Gender, Sexuality and Children" (2016) 36 Child Leg Rts $\mathrm{J} 90$ at 101.

81 Consider Glennon, supra note 79 at 930-31; Corrado, Kuehn \& Margaritescu, supra note 59 at 53; Minaker, supra note 34 at 300; Goel, supra note 40 at 38-39; Ontario Human Rights Commission, supra note 80 at 25; Mayes, supra note 80 at 101; Lars Noah, "Pigeonholing Illness: Medical Diagnosis as a Legal Construct" (1999) 50 Hastings LJ 241 at 244 45; Aneshensel, Phelan \& Bierman, supra note 47 at 3.

82 White, supra note 40 at 430.

83 Ibid.

84 Ibid at 430, 438; Jennifer A Chandler, "The Impact of Biological Psychiatry on the Law: Evidence, Blame, and Social Solidarity" (2017) 54 Alta L Rev 831 at 841.

85 See Glennon, supra note 79 at 931; Cho, Williams Crenshaw \& McCall, supra note 33 at 797; Minaker, supra note 34 at 292, 300.

86 Glennon, supra note 79 at 931; King et al, supra note 56 at 91, 100; Goel, supra note 40 at 38-39; Mosoff et al, supra note 59 at 438-39; Corrado, Kuehn \& Margaritescu, supra note 59 at 41, 53-55; Nichols \& Braimoh, supra note 44 at $161-62$.

87 Consider Goel, supra note 40 at 37-39, 52; White, supra note 40 at 430, 438-39. 


\section{THE MULTIFACETED CHILD: OVERLOOKED COMPLEXITIES}

\section{A. Characteristics and Demographics: A Picture of Interlocking Oppression and Inequality}

Children who are engaged with the family law (child welfare) and youth criminal justice systems, particularly those with mental health issues, often face numerous challenges (e.g. trauma, poverty, cognitive impairments, etc.). ${ }^{88}$ There are nearly ten thousand children in care on average each month in Ontario. ${ }^{89}$ Children who are taken into care by the CAS have been subjected (or, at least have been determined to have been subjected) to some form(s) of maltreatment or risk of harm (e.g. physical, sexual or emotional abuse, neglect). ${ }^{90}$ Research suggests that children who are exposed to maltreatment are at an increased risk of experiencing behavioural, mental health, and/or substance abuse issues and of becoming involved in the criminal justice system. ${ }^{91}$ Research also suggests that the occurrence and nature of the given (negative) outcomes actually experienced by maltreated children is often related to the interaction of a variety of factors (e.g. genetics, age, type, severity and chronicity of maltreatment, poverty, parental functioning issues). ${ }^{92}$

While each child is an individual with unique life experiences, ${ }^{93}$ the disproportionate prevalence of certain characteristics and environmental factors amongst children in care is notable. The rate of mental health issues is higher amongst children in care than children who are not engaged with the CAS, with studies estimating that almost two-thirds of children in care have diagnosed mental disorders, and that many more likely have undiagnosed mental health issues. ${ }^{94}$ Many children who are engaged with the CAS come from single parent families, and from households struggling with poverty, repeated moves, lack of social supports, and/or caregiver functioning issues (e.g. mental health or addiction issues). ${ }^{95}$

88 Smith et al, "Role Specialization and Service Integration", supra note 19 at 139; Lil Tonmyr et al, supra note 19 at 493; Bala et al, supra note 5 at 130, 134-35; Scully \& Finlay, supra note 5 at 25-26, 2-3.

89 "Facts and Figures" (2018), online: Ontario Association of Children's Aid Societies <www.oacas.org/childrens-aid-child protection/facts-and-figures/>.

90 Scully \& Finlay, supra note 5 at 2; Van Wert et al, supra note 5 at 50; Bala et al, supra note 5 at 135.

91 Van Wert et al, supra note 5 at 50, 58; Bala et al, supra note 5 at 135, 139; Scully \& Finlay, supra note 5 at 3; Melissa Jonson-Reid \& Richard P Barth, "From Maltreatment Report to Juvenile Incarceration: The Role of Child Welfare Services" (2000) 24 Child Abuse \& Neglect 505 at 507, 511, 517.

92 Van Wert et al, supra note 5 at 50; Bala et al, supra note 5 at 135; As I describe below, the outcomes experienced by maltreated children may also be shaped by the provision, or failure to provide, adequate supports and services (consider Scully \& Finlay, supra note 5 at 2, 25; Bala et al at 139; Van Wert et al at 59; Jonson-Reid \& Barth, supra note 91 at 519).

93 Consider Bala et al, supra note 5 at 134.

94 Scully \& Finlay, supra note 5 at 3; Bala et al, supra note 5 at 139; Consider also Chuang \& Wells, supra note 5 at 1814; Van Wert et al, supra note 5 at 59; Philip Burge, "Prevalence of Mental Disorders and Associated Service Variables Among Ontario Children Who Are Permanent Wards" (2007) 52 Can J Psychiatry 305 at 312; Jane Kovarikova, Exploring Youth Outcomes After Aging-Out of Care (Toronto: Office of the Provincial Advocate for Children and Youth, April 24, 2017) at 16, 24.

95 Carrie Smith et al, "Child Welfare Organizations: Do Specialization and Service Integration Impact Placement Decisions?" (2018) 76 Child Abuse \& Neglect 573 [Smith et al, "Child Welfare Organizations: Placement Decisions"] at 574; A Jud, B Fallon \& N Trocmé, "Who Gets Services and Who Does Not? Multi-level Approach to the Decision for Ongoing Child Welfare or Referral to Specialized Services" (2012) 34 Children \& Youth Services Rev 983 at 983, 987, 988; Joanne Filippelli et al, "Infants and the Decision to Provide Ongoing Child Welfare Services" (2017) 11:24 Child \& 
Children of Indigenous or certain racial backgrounds are, as Bryn King et al argue, "more likely to be referred for suspected maltreatment, to be substantiated as victims, to be placed in out-of-home care, and to remain in care for longer periods of time than White children". ${ }^{96}$ For example, studies suggest that Indigenous children are investigated at considerably higher rates than non-Indigenous children and that they comprise a disproportionate number (a significant overrepresentation) of children in care. ${ }^{97}$ Research also suggests that Black children are more likely to be reported to CAS and to be investigated than White children and also are overrepresented (in comparison to the proportion of Black children in the general population) in terms of rates of substantiation, referral to ongoing services, and out-of-home placement. ${ }^{98}$ And, disproportionality and disparity also has been observed in the youth criminal justice system and in rates of detention, with Indigenous children and Black children being overrepresented in this system as well. ${ }^{99}$

A disproportionate prevalence of mental health issues also has been observed in the youth criminal justice system, with studies suggesting that more than ninety percent of children who are engaged with this system experience mental health issues. ${ }^{100}$ Many children who become engaged with the youth criminal justice system have experienced trauma and a disproportionate number are involved with the

Adolescent Psychiatry \& Mental Health 1 [Filippelli et al, "Infants and Ongoing Services"] at 3, 10; Joanne Filippelli et $a l$, "Infants Investigated by the Child Welfare System: Exploring a Distinct Profile of Risks, Service Needs, and Referrals for Support in Ontario" (2017) 7:101 Brain Sciences 1 [Filippelli et al, "Infants Investigated"] at 4; Barbara Fallon et al, "Opportunities for Prevention and Intervention with Young Children: Lessons from the Canadian Incidence Study of Reported Child Abuse and Neglect" (2013) 7:4 Child \& Adolescent Psychiatry \& Mental Health 1 [Fallon et al, "Opportunities for Prevention"] at 11, 12; J K Stoddart et al, "Substantiated Child Maltreatment: Which Factors Do Workers Focus on When Making this Critical Decision?" (2018) 87 Children \& Youth Services Rev 1 at 2, 6, 7; Mosoff et al, supra note 59 at 440 ; See also eg $D(D)$, supra note 54 at para 29.

96 Supra note 56 at 89, 91; Consider also Scully \& Finlay, supra note 5 at 5; Joseph P Ryan et al, "Maltreatment and Delinquency: Investigating Child Welfare Bias in Juvenile Justice Processing" (2007) 29 Children \& Youth Services Rev 1035 at 1037, 1047; Herz et al, supra note 11 at 16; It is beyond the scope of this article to discuss the complex and interrelated factors that may explain the overrepresentation of Indigenous children and children from certain racial minority groups in both the family law (child welfare) and criminal justice systems (e.g. racial bias, over-policing, intergenerational impact of colonialism, lack of adequate support services) (see Sinha et al, supra note 62; Corrado, Kuehn \& Margaritescu, supra note 59; Ontario Human Rights Commission, supra note 80).

97 Sinha et al, supra note 62 at 828-29, 822-23; King et al, supra note 56 at 91; Barbara Fallon et al, Ontario Incidence Study of Reported Child Abuse and Neglect-2013 (OIS-2013) (Toronto: Child Welfare Research Portal, 2015) at 65-67; Ontario Human Rights Commission, supra note 80 at 7, 16, 17, 46.

98 King et al, supra note 56 at 91, 99-100 (King et al also note that the reporting of Black children at disproportionate and disparate rates may explain the overrepresentation observed at later stages of the child welfare process); Consider also Ryan et al, supra note 96 at 1047; Ontario Human Rights Commission, supra note 80 at 21, 24.

99 Scully \& Finlay, supra note 5 at 5; Corrado, Kuehn \& Margaritescu, supra note 59 at 40-41, 45; Statistics Canada, Youth Correctional Statistics in Canada, 2015/2016, by Jamil Malakieh, Canadian Centre for Justice Statistics, Catalogue No 85-002-X (Ottawa: Minister of Industry, March 1, 2017) at 5; Canada, Office of the Correctional Investigator \& Office of the Provincial Advocate for Children and Youth (Ontario), Missed Opportunities: The Experience of Young Adults Incarcerated in Federal Penitentiaries, Catalogue No PS104-15/2017 (Canada: Her Majesty the Queen in Right of Canada, August 31, 2017) at 13; Consider also King et al, supra note 56 at 91; Glennon, supra note 79 at 938 ; Ryan et al, supra note 96 at 1037, 1047; Herz et al, supra note 11 at 2.

100 McCormick, Peterson-Badali \& Skilling, supra note 5 at 213; Peterson-Badali et al, supra note 5 at 6-7; Consider also Chuang \& Wells, supra note 5 at 1814; Bala et al, supra note 5 at 139; Scully \& Finlay, supra note 5 at 3; Freedman, Wong \& Corrado, supra note 5 at 139-40. 
CAS (in many cases having been placed in group homes). ${ }^{101}$ Once these children, particularly those in group homes, have been involved with the youth criminal justice system, many tend to become enmeshed in a "vicious cycle" or "revolving door" that sees them repeatedly coming before the criminal Courts. ${ }^{102}$

Children in care are more likely to be charged, detained and sentenced to custody than youth who are not engaged with the CAS. ${ }^{103}$ Children in out-of-home placements, particularly those residing in group homes, are reported to police more frequently than their counterparts in the general population, often for minor offences (e.g. pushing someone). ${ }^{104}$ Once children in care have become engaged with the youth criminal justice system, many find themselves facing additional (repeated) charges for "administration of justice" offences. ${ }^{105}$ These offences primarily involve breaches of the conditions imposed on the child through bail or probation orders, such as missing a curfew. ${ }^{106}$ Once a child has been found guilty of breaching more than one non-custodial sentence, they may be committed to custody. ${ }^{107}$ Studies have found that one in six children in care have been in custody, compared to less than one in fifty in the general population. ${ }^{108}$

Children in care are about half as likely to graduate from high school as are their counterparts in the general population. ${ }^{109}$ Studies have found that children in care are more likely to become involved in the youth criminal justice system than they are to graduate from high school. ${ }^{110}$ Once involved with both systems, the chances a youth will graduate from high school drops even more dramatically. ${ }^{11}$ Low educational achievement is just one of many negative long-term consequences experienced by youth in care. ${ }^{12}$ These youth also experience high rates of homelessness or unstable housing, unemployment or

101 Freedman, Wong \& Corrado, supra note 5 at 139, 141, 150; Scully \& Finlay, supra note 5 at 2, 5; Bala et al, supra note 5 at 133-35, 139-40; Jonson-Reid \& Barth, supra note 91 at 511, 517; Corrado, Kuehn \& Margaritescu, supra note 59 at 52.

102 Malla et al, supra note 1 at 217, 219; Bala et al, supra note 5 at 135-37, 139, 142, 149; Scully \& Finlay, supra note 5 at 2-3, 6, 25; Office of the Provincial Advocate for Children and Youth for Ontario, supra note 7 at 3; Brown, Jones \& Greiner, supra note 33 at 164.

103 Bala et al, supra note 5 at 133-34, 139-40; Scully \& Finlay, supra note 5 at 5-6; Freedman, Wong \& Corrado, supra note 5 at 139, 150; Justice Malcolm McLeod, "The Ashley Smith Story - A Judge's Perspective" (2012) 59 Crim LQ 237 at 262; Kovarikova, supra note 94 at 20-22; I describe the foregoing to demonstrate how children in care tend to become involved, repeatedly, in the youth criminal justice system. I note that, while being in care has been identified as a factor associated with engagement in the youth criminal justice system, this engagement has also been correlated to a number of other factors, many of which are also the factors correlated with a child becoming engaged with the CAS in the first place (e.g. maltreatment, trauma, residential instability) (see Freedman, Wong \& Corrado; Bala et al; Scully \& Finlay).

104 Kovarikova supra note 94 at 20,21,33; See also Bala et al, supra note 5 at 135-38; Scully \& Finlay, supra note 5 at 4; McLeod, supra note 103 at 262.

105 Bala et al, supra note 5 at 134; McLeod, supra note 103 at 262; Scully \& Finlay, supra note 5 at 6.

106 Bala et al, supra note 5 at 134, 136, 138-39; McLeod, supra note 103 at 262; Scully \& Finlay, supra note 5 at 6.

107 YCJA, supra note 44, s 39(b); McLeod, supra note 103 at 262, 263-64; See also Scully \& Finlay, supra note 5 at 6; Bala et al, supra note 5 at $138-39$.

108 Bala et al, supra note 5 at 134; Scully \& Finlay, supra note 5 at 5; Freedman, Wong \& Corrado, supra note 5 at 139.

109 Kovarikova, supra note 94 at 10; Bala et al, supra note 5 at 134.

110 Bala et al, supra note 5 at 134; Scully \& Finlay, supra note 5 at 5.

111 Bala et al, supra note 5 at 134.

112 Kovarikova, supra note 94 at 6; Ontario Human Rights Commission, supra note 80 at 28. 
underemployment, low income, social assistance and poverty, physical and mental health issues, early pregnancy, and ongoing involvement with the criminal justice system. ${ }^{113}$

\section{B. Interlocking Oppression and Inequality: Systemic Perpetuation}

Individual and environmental factors may act to insulate children from experiencing the risks associated with challenges and disadvantages (e.g. childhood trauma) or they may act as aggravating factors, increasing children's vulnerability and the likelihood they will experience negative outcomes (e.g. aggression, engagement in the criminal justice system). ${ }^{114}$ The nature of the outcomes experienced by children who have been maltreated may be shaped by the intersection of various individual and environmental factors (e.g. genetics, gender, socioeconomic status, treatment provision). ${ }^{115}$ As Melissa Van Wert et al note, "[t]he accumulation and interaction of negative influences at the individual, family, neighborhood, and societal levels are generally considered more detrimental to child development than any single risk or disadvantage". ${ }^{116}$

Children who are engaged with the family law (child welfare) and youth criminal justice systems often face multiple challenges and disadvantages, including trauma (e.g. abuse, neglect), childhood functioning issues (e.g. mental health issues, learning difficulties), poverty, multiple housing disruptions, lack of social supports, etc. ${ }^{117}$ The prevalence and extent of the challenges and disadvantages experienced by these children may be compounded and exacerbated (or ameliorated) by the child and family's characteristics and social positions (e.g. race, sexual orientation, socioeconomic status, access to resources). ${ }^{118}$ For example, King et al found that "Black children reported for maltreatment-related concerns in Ontario in 2013 also experienced a number of socioeconomic risk factors in excess of their White counterparts", with Black families being "less likely to be working full time or living in their own home, but more likely to receive social assistance or other benefits, experience severe economic hardship, and live in overcrowded housing". ${ }^{119}$ In other words, the context in which children and families become engaged with the family

113 Kovarikova, supra note 94 at 6, 9, 26; Ontario Human Rights Commission, supra note 80 at 28; See also Office of the Correctional Investigator \& Office of the Provincial Advocate for Children and Youth, supra note 99 at 19.

114 See Van Wert et al, supra note 5 at 50; Consider also Cairney, Veldhuizen \& Wade, supra note 34 at 51-53; Mayes, supra note 80 at 91 .

115 See Van Wert et al, supra note 5 at 50; Goel, supra note 40 at 28; Corrado, Kuehn \& Margaritescu, supra note 59 at 41 ; Consider also Cairney, Veldhuizen \& Wade, supra note 34 at 51-53; Mayes, supra note 80 at 91.

116 Supra note 5 at 50.

117 Smith et al, "Role Specialization and Service Integration", supra note 19 at 139; Tonmyr et al, supra note 19 at 493 ; Bala et al, supra note 5 at 130, 134-35; Scully \& Finlay, supra note 5 at 25-26, 2-3; Van Wert et al, supra note 5 at 50; Smith et al, "Child Welfare Organizations: Placement Decisions", supra note 95 at 574; Jud, Fallon \& Trocmé, supra note 95 at 983, 987, 988; Filippelli et al, "Infants and Ongoing Services", supra note 95 at 3, 10; Filippelli et al, "Infants Investigated", supra note 95 at 4; Fallon et al, "Opportunities for Prevention", supra note 95 at 11, 12; Stoddart et al, supra note 95 at 2, 6, 7; Mosoff et al, supra note 59 at 440.

118 King et al, supra note 56 at 101-02; Sinha et al, supra note 62 at 823, 828-29; Corrado, Kuehn \& Margaritescu, supra note 59 at 41; Consider also Mayes, supra note 80 at 91; Van Wert et al, supra note 5 at 50; White, supra note 40 at 438 ; Goel, supra note 40 at 34; Brown, Jones \& Greiner, supra note 33 at 164.

119 Supra note 56 at 101; "Severe economic hardship" was defined as "running out of money for food, utilities, or housing" (ibid). It is beyond the scope of this article to discuss the structural and systemic factors relating to the higher rates of poverty amongst various marginalized groups (see ibid at 102; See also Ontario Human Rights Commission, supra note 80 at 23). 
law (child welfare) and youth criminal justice systems, and their experiences in these systems, may be shaped by the "intersectional impact" of various factors, including poverty, racism, and sexism. ${ }^{120}$

\section{Consequences of Failing to Recognize the Individual is More Than the Sum of Its Parts}

While certain patterns are discernible, not all maltreated children face the same challenges and disadvantages, and individual children will respond differently to the intersection of different individual and environmental factors. ${ }^{121}$ Personalizing the issues experienced by maltreated children, and acknowledging them only at the individual level (e.g. diagnosis of a mental "disorder" within the child), ignores and perpetuates societal discrimination and the interlocking oppressions and inequalities in which children's lives are embedded. ${ }^{122}$ This narrow focus excludes from consideration the structural and systemic factors that condition the experiences of the child (and family), and that create or heavily contribute to the circumstances that bring the child (and family) to the attention of the legal system. ${ }^{123}$

In order to be able to understand and to adequately address the needs of children with mental health issues who are engaged in the family law (child welfare) and youth criminal justice systems, it is important to consider and address both individual and environmental factors. ${ }^{124}$ Thus while, for example, psychotropic medications may help to alleviate the negative "symptoms" experienced by a child with a mental health issue, addressing the matter solely with individual medical interventions (pursuant to the medical model) may not address the root causes of the mental health issue or assist in addressing the other challenges the child may be facing. ${ }^{125}$ While they may provide a child with some relief from the symptoms of a mental health issue, psychotropic medications cannot provide that child with regular nutritious meals, a stable home, a positive and supportive caregiver, or the educational continuity they have lacked due to repeated moves. In order to treat the "whole child" it is important to acknowledge and address not only single issues (e.g. a mental "disorder"), but also the existence or absence and intersection of the various other factors (e.g. trauma, poverty, sexual orientation) that may engender and shape the lived experiences of the child. ${ }^{126}$

120 See King et al, supra note 56 at 101-03; Sinha et al, supra note 62 at 822-23, 828-29; Corrado, Kuehn \& Margaritescu, supra note 59 at 41, 53; Goel, supra note 40 at 40, 52; White, supra note 40 at 438; Brown, Jones \& Greiner, supra note 33 at 164; Ontario Human Rights Commission, supra note 80 at 7-8.

121 Consider Mayes, supra note 80 at 91; Van Wert et al, supra note 5 at 50; Goel, supra note 40 at 51-52.

122 Consider Minaker, supra note 34 at 292, 293; Williams, supra note 35 at 95; Goel, supra note 40 at 51-52; Corrado, Kuehn \& Margaritescu, supra note 59 at 53; Scully \& Finlay, supra note 5 at 25.

123 See Goel, supra note 40 at 51-52; Minaker, supra note 34 at 292, 300-02; Mosoff et al, supra note 59 at 461, 438-39; Corrado, Kuehn \& Margaritescu, supra note 59 at 53.

124 Consider Corrado, Kuehn \& Margaritescu, supra note 59 at 53, 41; Van Wert et al, supra note 5 at 59; Mosoff et al, supra note 59 at 461, 438-39; Mayes, supra note 80 at 104-05, 92; Glennon, supra note 79 at 936; Cho, Williams Crenshaw \& McCall, supra note 33 at 787-88; Nichols \& Braimoh, supra note 44 at 159; Sinha et al, supra note 62 at 829.

125 Yolanda Lambe, Drugs in Our System: An Exploratory Study on the Chemical Management of Canadian Systems Youth (Ottawa: National Youth Care Network, 2009) at 24, 20, 26; B Klein et al, "Diagnosing Attention-Deficit Hyperactivity Disorder (ADHD) in Children Involved with Child Protection Services: Are Current Diagnostic Guidelines Acceptable for Vulnerable Populations?" (2014) 41 Child: Care, Health \& Development 178 at 181-83; Consider also Bala et al, supra note 5 at $141,144$.

126 Consider Goel, supra note 40 at 51-52; Minaker, supra note 34 at 300; Mayes, supra note 80 at 104-06, 98, 92; Glennon, supra note 79 at 936; Van Wert et al, supra note 5 at 59; Corrado, Kuehn \& Margaritescu, supra note 59 at 41, 53. 
Thomas A. Mayes illustrates the need to account for various considerations with a number of case scenarios, including: "an LGBTQ [lesbian, gay, bisexual, transgender, or questioning] child with a physical disability is placed in a family foster home that is physically accessible; however, the family foster home does not have the resources to address the needs arising from the child's sexual orientation or gender identity", and "an LGBTQ child is set to be placed in an adoptive home of the child's same race based on the child's close identification with her heritage; however, the prospective adoptive family holds heterosexist views". ${ }^{127}$ As Mayes goes on to ask, ultimately, which of these "children's needs are met and which needs go unmet? Who answers this question? Fundamentally, why is this even a permissible question to ask?". ${ }^{128}$ Unfortunately, the needs of many children with mental health issues who are engaged with the family law (child welfare) and youth criminal justice systems go unmet, often compounding and further exacerbating the disadvantages experienced by this extremely vulnerable population. ${ }^{129}$

\section{INTERSECTIONAL ANALYSIS: A MEANS TO PROTECT CHILDREN WITH MENTAL HEALTH ISSUES}

An intersectional perspective recognizes the multiplicative effects of the intersection of various characteristics, and related social positions. ${ }^{130}$ Where an intersectional analysis is undertaken, underlying dominant (majority) perceptions and biases are questioned, the role of social structures and systems (e.g. the family law (child welfare) and youth criminal justice systems) in creating and sustaining marginalization and subordination are emphasized, and the interlocking oppressions and inequalities experienced by children and families are illuminated. ${ }^{131}$ Attention is drawn to the broad and overarching systemic issues (e.g. racism, patriarchy, economic inequality) that impact the lives of children and families and construct the "risk factors" that they experience (e.g. poverty, violence, family dysfunction, inadequate education). ${ }^{132}$ This analysis allows for a deeper and more contextual understanding of the complex needs of the children (and families) engaged with the family law (child welfare) and youth criminal justice systems, and exposes the potential of various services and systems (e.g. mental health, education) to more adequately meet those needs. ${ }^{133}$

127 Supra note 80 at 105, 90; Consider also Glennon, supra note 79 at 936.

128 Supra note 80 at 106.

129 Van Wert et al, supra note 5 at 59; Filippelli et al, "Infants Investigated", supra note 95 at 15, 2; Philip Baiden \& Barbara Fallon, "Examining the Association between Suicidal Behaviors and Referral for Mental Health Services among Children involved in the Child Welfare System in Ontario, Canada" (2018) 79 Child Abuse \& Neglect 115 at 122; Burge, supra note 94 at 306; Jill A Hoffman et al, "Child Welfare Caseworkers' Perspectives on the Challenges of Addressing Mental Health Problems in Early Childhood" (2016) 65 Children \& Youth Services Rev 148 at 152-54; Krista M Davis et al, "A Process Evaluation of Toronto's First Youth Mental Health Court” (2015) 57 Can J Corr 159 at 174; Scully \& Finlay, supra note 5 at 2-3, 25; Bala et al, supra note 5 at 139, 151; Chuang \& Wells, supra note 5 at 1814; Peterson-Badali et al, supra note 5 at 6-7.

130 Brown, Jones \& Greiner, supra note 33 at 179; Cho, Williams Crenshaw \& McCall, supra note 33 at 787, 795; Cairney, Veldhuizen \& Wade, supra note 34 at 56; MacKinnon, supra note 35 at 1020-21; Mayes, supra note 80 at 92.

131 Cho, Williams Crenshaw \& McCall, supra note 33 at 795-97; MacKinnon, supra note 35 at 1020-21; Minaker, supra note 34 at 292, 297-300; Cairney, Veldhuizen \& Wade, supra note 34 at 63; Mayes, supra note 80 at 106.

132 Minaker, supra note 34 at 299-300.

133 Ibid at 302-04; Mayes, supra note 80 at 92; Glennon, supra note 79 at 931-32; Goel, supra note 40 at 4; Corrado, Kuehn \& Margaritescu, supra note 59 at 54; King et al, supra note 56 at 102; Scully \& Finlay, supra note 5 at 25. 
The adoption of an intersectional analysis in decision making surrounding crossover youth would require resources, training, and buy-in from stakeholders. The implementation may be met with resistance and would require time and financial commitments in sectors that are already operating with limited resources. Compiling the information needed to fully understand the child's circumstances would likely require communication and collaboration across service sectors and providers (e.g. children's aid workers, probation officers). ${ }^{134}$ This may require a considerable shift, as the service sectors and service providers engaged with crossover youth tend to operate largely in isolation from one another. ${ }^{135}$

Implementation would have to be monitored and evaluated to ensure that, in practice, consideration of the child's social context and circumstances leads to outcomes that are responsive to the multiplicative challenges they experience, rather than leading decision makers to impose more restrictive or punitive interventions (as has been the case with some remedial legislative enactments, such as the sentencing provisions discussed earlier). ${ }^{136}$ For example, when presented with a child who does not have a home or cannot return to their previous residence (as is common where charges stem from incidents at that residence) a judge may be more inclined to sentence them to custody, despite the prohibition in the legislation against using custody "as a substitute for appropriate child protection, mental health or other social measures". ${ }^{137}$ Outside of the analysis itself, successful outcomes would depend on the availability of appropriate services and supports that are responsive to the specific needs of the child, which may pose a considerable obstacle in the face of limited or non-existent resources and programs. ${ }^{138}$

Despite the difficulties that may be associated with implementation, if supported by adequate resources, training, and buy-in from stakeholders, the adoption of an intersectional analysis in decision making offers a means to better assess and meet the needs of crossover youth. With early intervention and adequate supports and services, some of the trauma and consequences (e.g. less education, economic issues, poorer health, criminal activity) that arise from the compounding of disadvantages and the failure to meet the needs of the children (and families) engaged in the family law (child welfare) and youth criminal justice systems, may be avoided. ${ }^{139}$ Appropriate interventions may interrupt the "vicious cycle" which ensnares so many crossover youth, leading to better outcomes for them, and a decrease in the economic and other social costs associated with youth crime. ${ }^{140}$ Consider, for example, twin seventeen-year-old brothers, who were diagnosed with Fetal Alcohol Syndrome as babies and, despite the involvement in their lives of social services, health, education, and justice departments, had not received needed supports and

134 Bala et al, supra note 5 at $144-45,148$.

135 Bala et al, supra note 5 at 141, 142, 144-45.

136 Consider Bala et al, supra note 5 at 150, 151; Williams, supra note 35 at 80, 94; Corrado, Kuehn \& Margaritescu, supra note 59 at 53-54.

137 Bala et al, supra note 5 at 150; McLeod, supra note 103 at 273, 262; Scully \& Finlay, supra note 5 at 21, 26-27; Kovarikova, supra note 94 at 20; YCJA, supra note 44, ss 29(1), 39(5).

138 Consider Office of the Correctional Investigator \& Office of the Provincial Advocate for Children and Youth, supra note 99 at 20-21; Ontario Human Rights Commission, supra note 80 at 28, 18-19; Bala et al, supra note 5 at 142; Malla et al, supra note 1 at 220; Schwean \& Rodger, supra note 2 at 143-44; Peterson-Badali et al, supra note 5 at 19; McLeod, supra note 103 at $255 ; D(W A L)$, supra note 66.

139 Boyle \& Georgiades, supra note 49 at 217-18; Goel, supra note 40 at 4, 28, 52; Van Wert et al, supra note 5 at 59; Scully \& Finlay, supra note 5 at 2, 25; Glennon, supra note 79 at 940; Sinha et al, supra note 62 at 829; D (WAL), supra note 66 at para 42.

140 Bala et al, supra note 5 at 130, 142-43, 151; Scully \& Finlay, supra note 5 at 2, 10; Office of the Correctional Investigator \& Office of the Provincial Advocate for Children and Youth, supra note 99 at 19-20. 
services. ${ }^{141}$ The twins experienced various challenges, including educational disruption, confinement, and repeated involvement with the youth criminal justice system. ${ }^{142}$

That the twins had "appeared before the Youth Justice Court on an ongoing basis for over 4 years" and had "repeatedly been treated without regard" for their mental health issues, which "likely had a deleterious effect", was lamented by Justice Whelan in R. v. D. (W.A.L.) [D. (W.A.L.)]. ${ }^{143}$ In D. (W.A.L.), having found the twins unfit to stand trial on various property related offences, Justice Whelan extended considerable effort to bring together representatives from various governmental and community organizations and marshal "resources to provide them with support and supervision in the community" to "improve their living circumstances" and "prevent further and more serious criminal behaviour". ${ }^{144}$ Despite these efforts, the Court was limited by an inability to compel the government to provide programming, a lack of coordination between various governmental departments, and the scarcity of appropriate community supports and services. ${ }^{145}$ Ultimately "[ $\left.\mathrm{t}\right]$ he commitment was not" what the Court "had hoped", although the services arranged, including a "vocational assessment" and "alternate caregiver arrangement with the Aunt", were found to represent "progress in the living circumstances" of the twins. ${ }^{146}$ In fashioning the disposition granted in D. (W.A.L.), Justice Whelan took pains to understand the multifaceted and interactive challenges experienced by the twins, including functional issues and cognitive delays, educational difficulties and disruptions, difficulties with telling time and attending at scheduled activities, susceptibility to negative peer influences and anti-social behaviour, instability, and repeated criminal justice involvement, and to bring together supports and services to address these intersecting challenges (e.g. vocational assessments, respite and support workers to provide supervision and guidance and to assist with transportation and attendance at scheduled activities and appointments). ${ }^{147}$ Her Honour recognized that the challenges experienced by the boys (e.g. educational disruption, confinement) likely had been compounded and exacerbated because of the failure to "respond effectively" to their Fetal Alcohol Syndrome diagnosis and related needs at an earlier age. ${ }^{148}$ Her Honour also recognized that once people with Fetal Alcohol Spectrum Disorder have acquired "secondary disabilities" it becomes "doubly" challenging to develop supports and supervision to protect them and the community. ${ }^{149}$

The adoption of an intersectional approach by the governmental and legal actors who were engaged with the boys before they came to the attention of Justice Whelan as teenagers, would have recognized the intersecting individual and environmental factors affecting the well-being of these youths (e.g. cognitive delays, caregiver functional issues, instability, educational disruption) and the need for early intervention and appropriate services and consistent supports (e.g. specialized school programming, oneto-one coaching, pro-social activities tailored to their skills and interests, transportation to and from programs, support workers to provide respite and assistance to caregivers). ${ }^{150}$ Earlier and appropriate

141 D (WAL), supra note 66 at paras 3, 43, 44.

142 Ibid at paras 3, 42, 50.

143 Ibid at paras 3,43 .

144 Ibid at paras 1, 3, 4, 13, 26; See also $R v D(W A L)$ (2), $2004 \operatorname{SKPC} 42,61 \mathrm{WCB}$ (2d) 32 at paras 1, 3.

$145 D(W A L)$, supra note 66 at paras $3,36,37,81,85,88$.

146 Ibid at para 13.

147 Ibid at paras 6, 12-14, 42, 46, 50, 61-64, 83.

148 Ibid at paras 42-44.

149 Ibid at paras 43, 41.

150 Consider ibid at paras 44-46, 61, 83, 88. 
interventions likely would have spared these youth from some of the ongoing difficulties they experienced (e.g. educational disruption, repeated criminal involvement), and saved the associated costs for the Court, related personnel, and society more generally.

Part of adequately meeting the needs of children with mental health issues who are engaged with the family law (child welfare) and youth criminal justice systems is the provision of appropriate mental health services and supports which address distressing mental states and their underlying causes. ${ }^{151}$ However, in order to truly protect and promote the well-being of these children, the multiple challenges they face must be holistically addressed. ${ }^{152}$ It is only once all of the complex needs of the children who are engaged with the family law (child welfare) and youth criminal justice systems are fully addressed, that either system may be said to truly be meeting their statutory mandates and obligations to protect children and promote their well-being. ${ }^{153}$

\section{INTERSECTIONALITY AND MEETING CHILDREN'S MULTIFACETED NEEDS}

Intersectionality explores how various characteristics interact and produce simultaneously transformative effects that marginalize some and empower others, and how social structures and systems create and perpetuate these interlocking oppressions and inequalities. An intersectional analysis recognizes that the challenges and disadvantages experienced by marginalized individuals may be multiplicative and may be rooted in the systemic issues (e.g. racism, economic inequality) that construct the "risk factors" that bring many children and families to the attention of the family law (child welfare) and youth criminal justice systems (e.g. poverty, family dysfunction, mental health or addiction issues). Recognizing that the challenges faced by a child (and a family) may be interlocking and multiplicative allows for a broader understanding of needs and of the various supports and services required to adequately meet those needs.

The multifaceted needs of children with mental health issues who are engaged in the family law (child welfare) and youth criminal justice systems cannot be met adequately where a narrow focus, such as the individualistic focus often embraced by these legal systems, is adopted. Where, for example, a child is labelled as having a "mental disorder" and the cause is attributed to the child's biology, the "illness" is addressed by individual medical intervention (namely psychotropic medication). While this may alleviate some of the negative "symptoms" of the "illness", the characterization of a distressing mental state as an isolated, individual (medical) issue, masks the broader social disadvantages (e.g. poverty, racism) that may impact upon the child's mental health. Where the interlocking oppressions and inequalities experienced by these children are overlooked or ignored, their needs may not be adequately met and they may be further disadvantaged. In order for the family law (child welfare) and youth criminal justice

151 Van Wert et al, supra note 5 at 59; Scully \& Finlay, supra note 5 at 25; Goel, supra note 40 at 28; Glennon, supra note 79 at 940; Lambe, supra note 125 at 20, 25, 26, 30; Klein et al, supra note 125 at 181, 183; Consider also Boyle \& Georgiades, supra note 49 at 219-20; Krista M Davis, Michele Peterson-Badali \& Tracey A Skilling, "A Theoretical Evaluation of a Youth Mental Health Court Program Model" (2016) 45 Intl J L \& Psychiatry 17 at 18; Schwean \& Rodger, supra note 2 at $143-44,145$.

152 Van Wert et al, supra note 5 at 59; Corrado, Kuehn \& Margaritescu, supra note 59 at 54; Bala et al, supra note 5 at 131; Consider also McCormick, Peterson-Badali \& Skilling, supra note 5 at 219; Davis, Peterson-Badali \& Skilling, supra note 151 at $18,20-22$.

153 Consider Mayes, supra note 80 at 106; See also CYFSA, supra note 20, ss 1, 35(1); YCJA, supra note 44, s 3. 
systems to protect children and promote their well-being, the intersecting challenges faced by the children engaged with these systems must be recognized and addressed with adequate supports and services. Only then will these systems stop perpetuating the disadvantages experienced by the children in their care and, instead, start meeting their statutory mandates and obligations to this vulnerable population. 